\title{
Assessment of Knowledge and Attitude About Blood Donation among Nursing Students at Assiut University
}

\author{
Shaimaa M. Goda, Neama M .El-magrabi \& Safaa R. Mahmoud. \\ Clinical Demonstrator in Community Health Nursing Faculty of Nursing, Assuit University, Egypt. \\ Assistant Professor of Community Health Nursing Faculty of Nursing, Assuit University, Egypt. \\ Assistant Professor of Community Health Nursing Faculty of Nursing, Assuit University, Egypt.
}

\begin{abstract}
Every second for every day, people around the world of all ages need blood transfusions to survive. Millions of blood units were collected from donors every year but demands are increasing day by day that is pushing for sufficient and timely provision of blood donation .Aim : To assess knowledge and attitude about blood donation among nursing students. Methods: descriptive design was used in this study. Convenient sample of 1445 students who participated in the study (433 males and 1012 females).Two tools were used for data collection, first tools-An Arabic structured self-administrative questionnaire sheet which consisted of two parts : part one was personal characteristic, second part are include knowledge about blood donation second tools- Attitude scale developed by Manikandan etal ,2013 toward blood donation. Results: The mean studied students was $19.51 \pm 1.90$, around two thirds of them were female and had satisfactory knowledge about blood donation .conclusion :small percent of studied students had good level of knowledge regarding blood donation, the vast majority of them had positive attitude.Recommendation: Increase the awareness of students regarding blood donation through visual aids(picture and poster).The curriculum components of nursing students should be include the basic part about blood donation from all its aspect
\end{abstract}

Keywords: Knowledge, Attitude, Nursing students \& Blood Donation.

\section{Introduction}

The requirement of blood and blood products in a country depends on the population, health care structure, prevalence of conditions requiring regular transfusions such as hemophilia and thalassemia .The developed countries are able to meet the demand of blood donation with well-structured health system and blood donation services, whereas developing countries suffer from limited number of voluntary donors due to ignorance, misperceptions and fears about the blood donation process(Manikandan et al., 2013 ).

Globally, it is estimated that more than 75 million units of blood are donated each year. Approximately $60 \%$ of this blood is donated in the developed countries. The World Health Organization (WHO) data analysis showed that in the developing countries, less than $40 \%$ of blood donations are from voluntary blood donors, while in the developed, these donors form $98 \%$ of ,blood donations ,WHO Also estimated that donation by $1 \%$ of a country population is the minimum blood required to meet a nation's most basic needs for blood. Donation rates are still less than $1 \%$ of the populations in many developing countries (Majeed \& Lafta, 2008, Olubiyi et al., 2014).

Safe blood is a critical component in improving the health care and in preventing the spread of infectious diseases globally. Millions of lives are saved each year through blood transfusions, but yet the quality and the safety of blood transfusion is still a concern, particularly in the developing countries. The reason for this includes blood collection from unsafe donors, poor laboratory procedures and the inadequate testing of blood( Devi et al., 2012 ).

A blood bank plays an important role in ensuring the supply of safe blood as and when required. It is also essential that the blood collection process does not harm either the donor or the recipient. This is achieved by having donor criteria and stringent screening of collected blood for possible Transfusion Transmissible Infections (TTIs]( Rehman et al., 2012).

Donor should appear generally well, the color of exposed skin and mucous membranes should be normal, with no jaundice, cyanosis, flushing or pallor, and no signs of skin infection, the venipuncture site should be clean, free from any skin lesions or scars and antecubital veins should be easily visible (WHO, 2012)

When blood is withdrawn, the donor's body immediately begins to replenish the blood. New cells are produced by bone marrow within 48 hours of donation, and all of the red blood cells the donor loses during donation are completely replaced within one to two months. Therefore, donating blood helps to stimulate the production of new blood cells. This process of replenishment can help body stay healthy 
and work more efficiently(Abialbon, 2013, Darega et al., 2015)

Donor-related complications was defined as symptoms occurring during or just after the donation. The complications were categorized into three groups: mild, moderate and severe. If the symptoms disappeared within seven days from the phlebotomy or did not require immediate medical attention the complication was categorized as mild such as fainting and hematoma. The remaining symptoms persisted seven days after the phlebotomy or complications requiring immediate medical attention ,these complications were categorized as moderate such as iron deficiency and nerve injury . While if the donor had symptoms at least one year after the phlebotomy (complications with long-term morbidity), the complication was then categorized as severe such as vasovagal reactions and arterial puncture (Sorensen, et al., 2008)

Community health nurses play an important role in counseling process for blood donors about promoting healthy lifestyles and make an important contribution to individual and community health. counseling contributes to the early diagnosis and treatment of conditions such as anemia, blood disorders and infections. This offers a crucial early entry point for the treatment and care of donors found to be infected and may contribute to delaying or preventing disease or complications ,Also community health nurses as counsellor may reduce adverse donor reactions, improve donor perceptions of the Blood Transfusion Services (BTS), encourage donors to recommend blood donation to friends and family and, most importantly, increase the likelihood of returning for future donation. This is particularly valuable for BTS in the process of transition from a reliance on first-time or family replacement donors to regular voluntary non-remunerated blood donors ( Delaney, 2011)

Nurses are responsible for the establishment of friendly and professional contact with donors, the provision of information about the procedure and possible complications from it, and the clarification of doubts focused on gaining donors and making them return for new donations. These actions contribute to donor satisfaction, as well as ensure quality and safety of the transfusion process which starts with blood donation. The welcome can be regarded as the humanization of donor care, providing a sense of security and comfort, and there by helping to minimize complications or adverse events that may arise from the donation procedure(Silva,2012)

\section{Significance of the Study}

As regards to circumstances of the country such as high prevalence of accidents and high incidence of blood diseases and that increase the need for blood transfusion, because the vital role of nurse in blood transfusion, this study was conducted. Also, due to the lack of awareness importance among the community of blood donation by volunteering and also not provide knowledge on blood donation in the nursing curriculum.

\section{Aim of the study}

To assess knowledge and attitude about blood donation among nursing student at Assiut University

\section{Research questions}

- Are the students have a good level of knowledge regarding blood

- donation?

- Are the students have a positive attitude regarding blood donation?

\section{Subject \& Methods \\ Research design}

Descriptive research design was used in this study.

Setting of the study

The study was conducted at Faculty of Nursing , Technical Nursing Institute and Technical Nursing School at Assiut University

\section{Sample}

Convenient sample ,The total number of studied student was 1445.The sample included 433 males and 1012 females from first and final academic years (2015-2016)

\begin{tabular}{|l|c|c|c|c|}
\hline \multirow{2}{*}{ Places } & \multicolumn{2}{|c|}{ Academic years } & \begin{tabular}{c} 
Total \\
number \\
\cline { 2 - 5 } of \\
students
\end{tabular} & $\begin{array}{c}\text { Total } \\
\text { number } \\
\text { of studied } \\
\text { students }\end{array}$ \\
\hline $\begin{array}{l}\text { Faculty of } \\
\text { Nursing }\end{array}$ & 439 & 504 & 943 & 751 \\
\hline $\begin{array}{l}\text { Technical } \\
\text { Nursing } \\
\text { Institute }\end{array}$ & 300 & 250 & 550 & 516 \\
\hline $\begin{array}{l}\text { Technical } \\
\text { Nursing } \\
\text { School }\end{array}$ & 100 & 90 & 190 & 178 \\
\hline Total & 839 & 844 & 1683 & 1445 \\
\hline
\end{tabular}

\section{Tools of the study}

Two tools were used to collect data for this study

Tool I: An Arabic structured self-administered sheet : It was designed and developed by the researchers after reviewing of different researches and pertinent literature for collection of data. It covers two parts

First part : socio-demographic characteristics for students included 9 questions regarding : age, sex, residence, institution, academic years ,father education, mother education, attending seminars 
about blood donation and if blood donate before

Second part : its included 17 questions about assessment knowledge ,such as amount of blood in the human body, component of blood, blood groups type , knowing yourself blood group, suitable age to donate blood,weight for the person who donates , hemoglobin level in person who donates, a normal blood pressure of a person donated , amount of blood that is taken from the donor, time required for donation, some diseases transmitted through blood donation, interval between two blood donations, tests before blood donation, contraindications of blood donation, benefits for blood donation, instruction that should be followed after the donation and complications after the donation.

\section{Tool II: Attitude scale toward blood donation}

It includes twenty statements regarding blood donation. All statements have response format (agree/ disagree). developed by (Manikandan et al., 2013),

The scale was carried out it contained positive and negative statements to allow for investigation of positive and negative students attitude .The eleven statement of positive attitudes were $1,2,4,6,7,9,10,11,14,15$ and 19 . While the negative attitude nine statements were 3,5,8,12,13,16,17,18,20

\section{Scoring System}

- Regarding knowledge total score

- One grade was given for each correct answer and zero was given for incorrect answer. The scores of each item were summed and then converted into a percent score. Poor score was less than $50 \%$, satisfactory score was ranged from 50-60\% and good score was more than 60\%.( Abd El Rhman, 2014)

- Regarding to the total scoring for attitude was considered as positive attitude if the score is more than $60 \%$ and negative attitude if the score less than $60 \%$ (Abd El Rhman, 2014 )

\section{Methodology \\ I-Pilot study}

Pilot study was carried out before starting of data collection on (145), which was included in the study because there wasn't any modifications in the form .The aim of pilot study is to test the clarity of the tool and to estimate the time needed for fulfilling it .

\section{II-Data collection phase \\ Ethical Considerations}

The study approved by Faculty of Nursing, Assiut University ethical committee. The students were recruited to the study informed about the objectives of the study and that they were free to refuse to participation .Oral consent was obtained from the studied student

\section{Field work}

Before starting the study, an official letter approval was obtained from the Dean of the Faculty of Nursing , Assiut University, to vice for students affairs at Faculty of Nursing and director of each setting , this letter included a permission to carry out the study and explained the purpose and nature of the study.

- The researcher gave the directors of each setting a copy of the official approval letter and asked them to take a copy of the study schedules of the selected grades of setting involved in this study.

- At the end of lecture, students asked to stay in their places, the researcher introduce herself to the teaching staff members for student's at each setting and reminded them of the nature and purpose of the study.

- The researcher obtained oral consent from each student to participate in the study.

- filling of questionnaire sheet took 20 -30 minutes by students

- Finally ,the researcher thanked the students and teaching staff for their cooperation

- Data was collected during the periods from October to mid-December of academic years 2015-2016

- The data was collected one day/week average number of student between 120-150/ meeting

\section{Statistical analysis}

- The obtained data were reviewed, prepared for computer entry, coded, analyzed and tabulated. Descriptive statistics were calculated i.e frequencies, percentage, mean and standard deviation. Variables were done using compared program SPSS version19. chi-square test and pearson correlation presence of a statistical significance with ranked variables. Statistical significance was considered at $\mathrm{p}$. value were less than $0.05(\mathrm{p}<0.05)$ 


\section{Results}

Table (1): Distribution of the studied students according to their sociodemographic characteristics at Assuit University, (N=1445).

\begin{tabular}{|c|c|c|}
\hline Socio-demographic characteristics & No & $\%$ \\
\hline \multicolumn{3}{|l|}{ Age } \\
\hline $15-$ & 951 & 65.8 \\
\hline$\geq 20$ & 494 & 34.2 \\
\hline Mean \pm SD (Range) & \multicolumn{2}{|c|}{$19.51 \pm 1.90(15.0-23.0)$} \\
\hline \multicolumn{3}{|l|}{ Sex } \\
\hline Male & 433 & 30.0 \\
\hline Female & 1012 & 70.0 \\
\hline \multicolumn{3}{|l|}{ Institution } \\
\hline Technical Nursing School & 178 & 12.3 \\
\hline Technical Nursing Institute & 516 & 35.7 \\
\hline Faculty of Nursing & 751 & 52.0 \\
\hline \multicolumn{3}{|l|}{ Academic years } \\
\hline First & 658 & 45.5 \\
\hline Final & 787 & 54.5 \\
\hline \multicolumn{3}{|l|}{ Father education } \\
\hline Illiterate & 164 & 11.3 \\
\hline Basic education & 231 & 16.0 \\
\hline Secondary & 673 & 46.6 \\
\hline University & 377 & 26.1 \\
\hline \multicolumn{3}{|l|}{ Mother education } \\
\hline Illiterate & 358 & 24.8 \\
\hline Basic education & 285 & 19.7 \\
\hline Secondary & 585 & 40.5 \\
\hline University & 217 & 15.0 \\
\hline \multicolumn{3}{|l|}{ Residence } \\
\hline Urban & 497 & 34.4 \\
\hline Rural & 948 & 65.6 \\
\hline \multicolumn{3}{|l|}{ Attending seminars about blood donation } \\
\hline Yes & 210 & 14.5 \\
\hline No & 1235 & 85.5 \\
\hline \multicolumn{3}{|l|}{ Blood donate before } \\
\hline Yes & 187 & 12.9 \\
\hline No & 1258 & 87.1 \\
\hline
\end{tabular}


Table (2): Distribution of the studied students' correct knowledge about blood and the criteria of blood donors at Assiut University, (N=1445).

\begin{tabular}{|c|c|c|}
\hline Item & No & $\%$ \\
\hline \multicolumn{3}{|c|}{ Amount of blood in the human body } \\
\hline Correct & 1224 & 84.7 \\
\hline \multicolumn{3}{|l|}{ Components of blood } \\
\hline Correct & 820 & 56.7 \\
\hline \multicolumn{3}{|l|}{ Blood groups } \\
\hline correct & 1224 & 84.7 \\
\hline \multicolumn{3}{|l|}{ Knowing yourself blood group } \\
\hline Yes & 748 & 51.8 \\
\hline No & 697 & 48.2 \\
\hline \multicolumn{3}{|l|}{ Suitable age to donate blood } \\
\hline Correct & 684 & 47.3 \\
\hline \multicolumn{3}{|l|}{ Weight for the person who donates } \\
\hline Correct & 1072 & 74.2 \\
\hline \multicolumn{3}{|c|}{ Hemoglobin level in person who donates } \\
\hline Correct & 546 & 37.8 \\
\hline \multicolumn{3}{|c|}{ Normal blood pressure of a donated person } \\
\hline Correct & 1378 & 95.4 \\
\hline \multicolumn{3}{|c|}{ mount of blood that can be donated by person } \\
\hline Correct & 448 & 31.0 \\
\hline \multicolumn{3}{|l|}{ Time required for donation } \\
\hline Correct & 974 & 67.4 \\
\hline \multicolumn{3}{|c|}{ * Some diseases transmitted through blood donation } \\
\hline Hepatitis B & 718 & 49.7 \\
\hline AIDS & 751 & 52.0 \\
\hline Hepatitis C & 828 & 57.3 \\
\hline Do not know & 257 & 17.8 \\
\hline \multicolumn{3}{|c|}{ Are there certain tests which should be done before blood donation? } \\
\hline Yes & 1140 & 78.9 \\
\hline No & 305 & 21.1 \\
\hline \multicolumn{3}{|l|}{ *Tests: $\mathbf{n}=1140$} \\
\hline Serology test & 661 & 58.0 \\
\hline Blood group type & 487 & 42.7 \\
\hline Hemoglobin level & 634 & 55.6 \\
\hline \multicolumn{3}{|c|}{ Interval between two blood donation among the same person } \\
\hline Correct & 580 & 40.1 \\
\hline
\end{tabular}

*more than one answer

The research question number one cover by table (2)

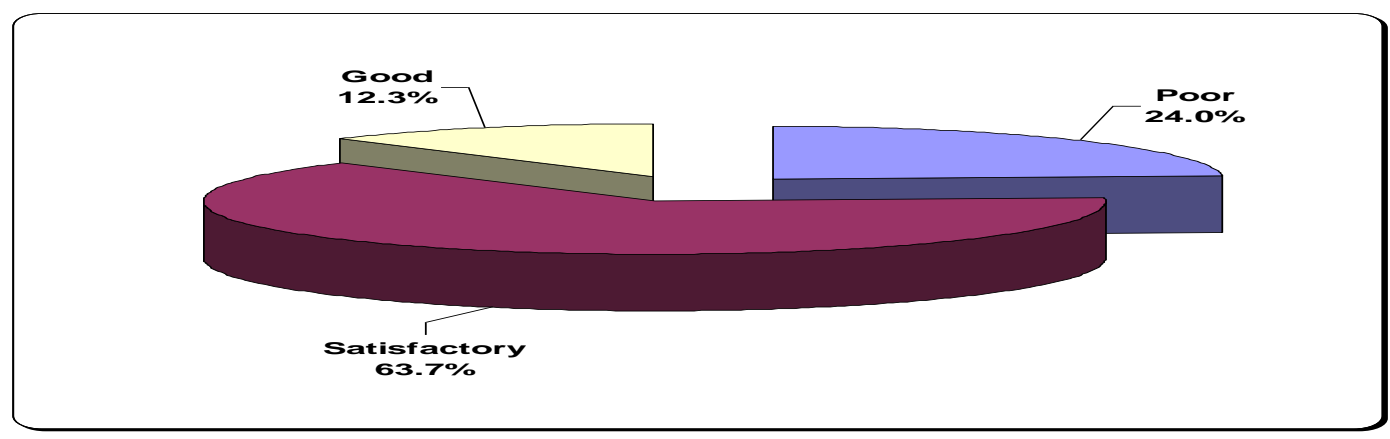

Fig(1):Total score of knowledge regarding blood donation among studied students at Assiut University,2015( $N=1445$ ) 
Table (3): Relation between studied students socio-demographic characteristics and their attitude toward blood donation at Assiut University, ( $\mathrm{N}=1445)$.

\begin{tabular}{|c|c|c|c|c|c|}
\hline \multirow{3}{*}{ socio-demographic characteristics } & \multicolumn{4}{|c|}{ Attitude } & \multirow{3}{*}{ P-value } \\
\hline & \multicolumn{2}{|c|}{$\begin{array}{l}\text { Negative attitude } \\
(n=113)\end{array}$} & \multicolumn{2}{|c|}{$\begin{array}{c}\text { Positive attitude } \\
(n=1332)\end{array}$} & \\
\hline & No. & $\%$ & No. & $\%$ & \\
\hline \multicolumn{5}{|l|}{ Age years } & \multirow{3}{*}{0.171} \\
\hline 15 & 81 & 71.7 & 870 & 65.3 & \\
\hline$\geq 20$ & 32 & 28.3 & 462 & 34.7 & \\
\hline \multicolumn{5}{|l|}{ Sex } & \multirow{3}{*}{$0.001 *$} \\
\hline Male & 49 & 43.4 & 384 & 28.8 & \\
\hline Female & 64 & 56.6 & 948 & 71.2 & \\
\hline \multicolumn{5}{|l|}{ Institution } & \multirow{4}{*}{$0.002 *$} \\
\hline Technical Nursing School & 25 & 22.1 & 153 & 11.5 & \\
\hline Technical Nursing institute & 30 & 26.5 & 486 & 36.5 & \\
\hline Faculty of Nursing & 58 & 51.3 & 693 & 52.0 & \\
\hline \multicolumn{5}{|l|}{ Academic year } & \multirow{3}{*}{0.915} \\
\hline First & 52 & 46.0 & 606 & 45.5 & \\
\hline Final & 61 & 54.0 & 726 & 54.5 & \\
\hline \multicolumn{5}{|l|}{ Father education } & \multirow{5}{*}{0.243} \\
\hline Illiterate & 8 & 4.9 & 156 & 95.1 & \\
\hline Basic education & 17 & 7.4 & 214 & 92.6 & \\
\hline Secondary & 51 & 7.6 & 622 & 92.4 & \\
\hline University & 37 & 9.8 & 340 & 90.2 & \\
\hline \multicolumn{5}{|l|}{ Mother education } & \multirow{5}{*}{0.800} \\
\hline Illiterate & 24 & 6.7 & 334 & 93.3 & \\
\hline Basic education & 22 & 7.7 & 263 & 92.3 & \\
\hline Secondary & 48 & 8.2 & 537 & 91.8 & \\
\hline University & 19 & 8.8 & 198 & 91.2 & \\
\hline \multicolumn{5}{|l|}{ Residence } & \multirow{3}{*}{0.316} \\
\hline Urban & 34 & 30.1 & 463 & 34.8 & \\
\hline Rural & 79 & 69.9 & 869 & 65.2 & \\
\hline \multicolumn{5}{|c|}{ Attending seminars about blood donation: } & \multirow{3}{*}{$0.019 *$} \\
\hline Yes & 8 & 7.1 & 202 & 15.2 & \\
\hline No & 105 & 92.9 & 1130 & 84.8 & \\
\hline
\end{tabular}

* Statistical significance difference at $p<0.05 \quad$ The research question number two cover by table (3)

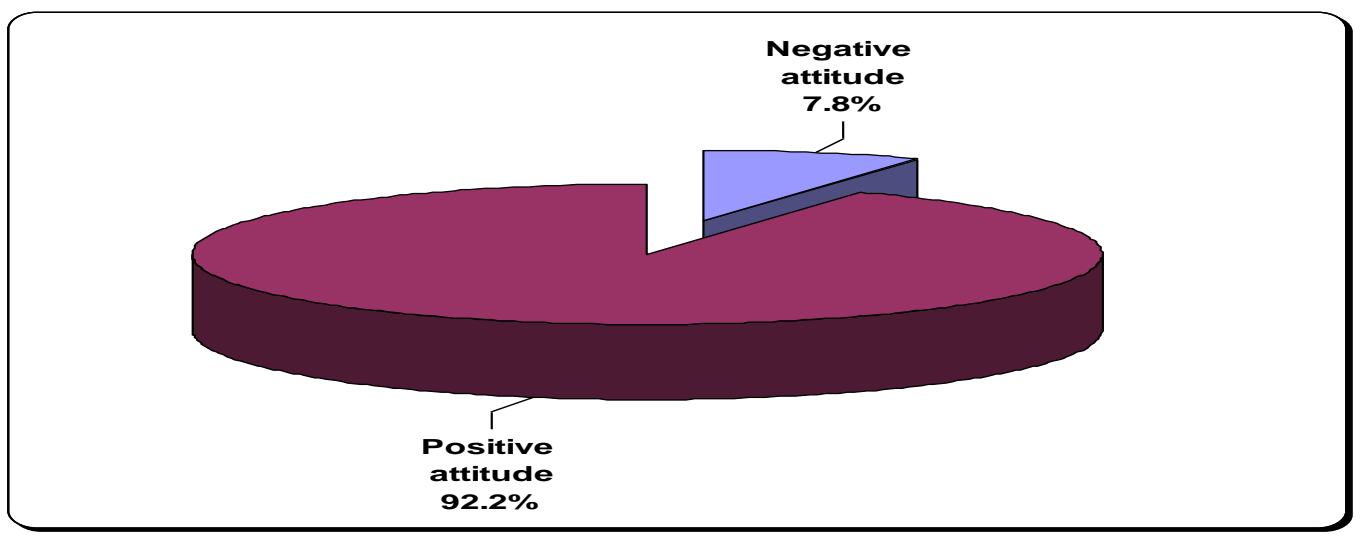

Fig(2):Shows total attitude score of studied students toward blood donation at Assiut University, 2015. 


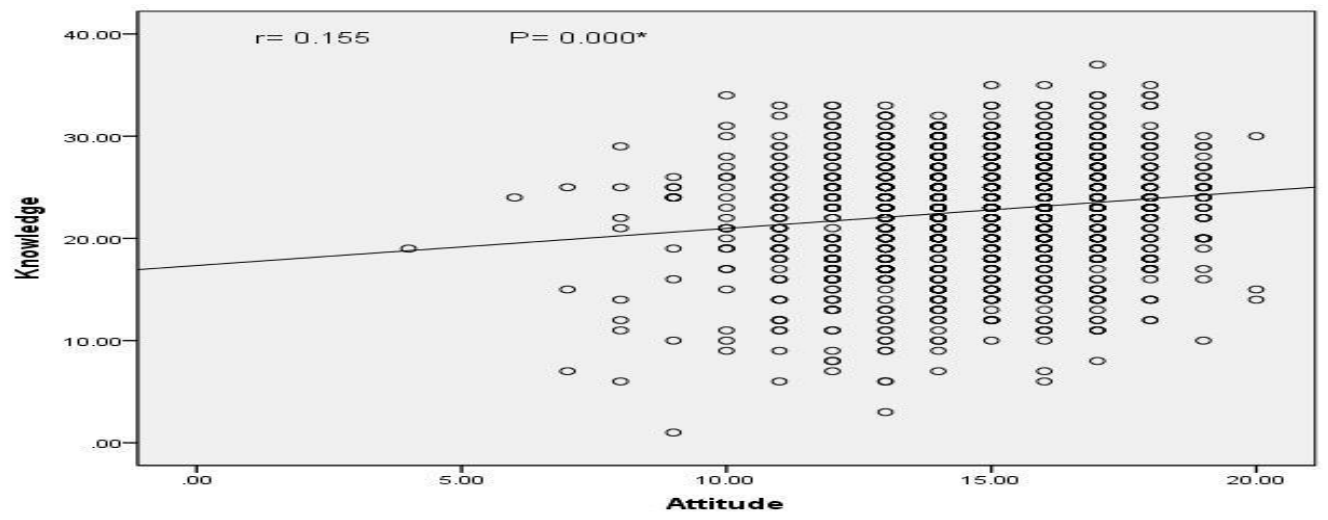

Figure (3): It was revealed that there is a positive correlation between student total score of knowledge and their attitude toward blood donation.

Table (1): Illustrated that the age group 15 to less than 20 years represent $65.8 \%$. While $52 \%$ of them were from Faculty of nursing, $35.7 \%$ of them from Technical Nursing Institute and the remains $12.3 \%$ were from the Technical Nursing School .Regarding to academic years, $45.5 \%$ of students were in the first academic years and $54.5 \%$ of students were in the final academic years. Concerning to residence , $65.6 \%$ of studied students were from rural area. $85.5 \%$ of studied students didn't attend any seminar about blood donation and $87.1 \%$ of them didn't donate blood before

Table (2): Shows $84.7 \%$ of the studied students gave correct answer about amount of blood in the human body, while $15.3 \%$ of them didn't know it. According to knowledge of studied students about component of blood, $56.7 \%$ of them mention correct answer and $43.3 \%$ of them answer incorrect.

Regarding to blood groups, $84.7 \%$ of studied students gave correct answer. While $48.2 \%$ of studied students didn't known yourself blood group.

Illustrates $47.3 \%$ of studied students have had correct answer regarding age to donate, While $74.2 \%$ of them know the weight for the person who donates. As regarding to the hemoglobin level in person who donates $37.8 \%$ of studied students have had correct answer about it ,Also $95.4 \%$ of them know is the normal blood pressure of a donated person

Reveals distribution of studied students regarding to amount of blood that can be donated by person, It was noticed $69 \%$ of the studied student gave incorrect answer. According to time required for donation , $67.4 \%$ of studied student known about it.

Aids and Hepatitis C were reported $57.3 \%$ of studied students as blood transmitted diseases through blood donation, Also this table show that,
59.9\% studied student have had incorrect answer regarding period between each time of donation.

Reveals that $78.9 \%$ of the studied students know the tests to be done before blood donation and $21.1 \%$ didn't know it, this results illustrated $58.0 \%$ of studied students mention serology test and $42.7 \%$ of them mention blood group type

Table (3): Show that there are A statistical significance difference between attitude of studied students and sex ,institution and attending seminars about blood donation but there is no statistical significance difference regarding age ,academic years and residence

Figure (1): This figure shows total score of students' knowledge about blood donation. It was found $63.7 \%$ of studied students had satisfactory knowledge, while $24 \%$ of them had poor knowledge and only $12.3 \%$ of them had good knowledge

Figure(2): Present of students $92.2 \%$ had positive attitude toward blood donation, While $7.8 \%$ of them were had a negative attitude toward blood donation

Figure(3): It was revealed that there is a positive correlation between student total score of knowledge and their attitude toward blood donation

\section{Discussion}

Blood donation is an essential component of an efficient and effective health system, saving millions of lives each year. Despite blood and blood products playing a crucial role in several facets of medical practice, many patients do not receive timely blood transfusion ( Mathias et al., 2014)

The present study shows that the mean age group of students' were $19.51 \pm 1.90$,it was ranged from 15 $\geq 20$, these results agree with Batiha \& Albashtaw, (2013), who conducted a study knowledge of Philadelphia university students regarding blood donation reported the age of student ranged from 18 $\geq 20$ 
According to the donation blood, the present study revealed that the majority of the studied students never donate blood before so it may be related to lack of time, tight lecture schedules and inadequate information about the voluntary blood donation to the donor, recipient and community, fear of infection and complication

This finding was in the same line with Shenga et al., (2008), who carried study behavior disparities toward blood donation in Sikkim reported that the majority of student studied never donate blood. Also agree with Manikandan et al., (2013), who conducted a study in Chennai to assess knowledge, attitude and practice on blood donation among health professional students that found the majority of studied student never donate blood .Also agree with Mirza et al., (2015) who study blood safety and donation knowledge, attitude and practice (KAP) among 1st Year Medical Students in Lahore, reported that the majority number of students had never donated blood.

As regards to amount of blood, the study illustrated that the majority of students knew the amount of blood in the human body. This results in contrast with Amayta, (2013), who study basied on Knowledge, Attitude and Practice of Blood Donation among Students of Different Colleges of Kathmandu, Nepal and he found that only $6.7 \%$ knew amount of blood in the human body. This is may be at their institution related to the student study about of blood physiology in academic years

Concerning the suitable age to donate blood, the current study indicated that more than two fifths of studied students gave correct answer and only less than two fifth of them did not know it. Because nursing students have aware that person who donates blood must be mature and his age have appropriate to donate

The current study was disagree with Chopra \& Jauhari, (2015), who study knowledge, attitude \& practices towards voluntary blood donation among medical students in Barabanki, they reported that the majority of studied students gave correct answer about suitable age to donate blood, also in contrast with kowsalya et al., (2013), who study on knowledge, attitude and practice regarding blood donation among students in puducherry, India who reported that the majority of studied students gave correct answer about suitable age to donate blood.

Regarding the weight required for donation blood, it was noticed that about three quarter of the studied students knew the weight for donating blood, this results agree with Giri \& Phalke, (2012), who conducted a study among undergraduate students of pravara institute of medical sciences Deemed University of Central India to assess knowledge and attitude about blood donation who found about three quarter of them knew weight required for donation blood

The current finding was in contrast with Safizadeh et al., (2007), who studied the university students awareness and attitude toward blood donation in Kerman City, who reported more than half of student knew about the necessary body weight for blood donation. The current study finding also disagree with Mortazavi \& Mahmoodizadh, (2008), who carried out his study to evulation of the awareness in zanjan university about blood donation eligibility criteria and found lower knowledge about the weight require for blood donation. Also, the finding was in disagreement with Singh et al., (2015), who carried out a study to blood donation awareness and beliefs among medical and nursing students in deemed university of rural kolar and reported that the majority of the students knew necessary body weight for blood donation.

According to hemoglobin level of person at the time of donation, the present study, more than one third of the studied students answer correct and revealed that less than two third of them answer incorrect, it may be due to lack of information in first weeks of study Regarding students' knowledge about the amount of blood that is taken from the donor, the result of the present study cleared that approximately one third of them knew that the collected blood volume among every blood donation. The same result was reported by Kowsalya et al., (2013), who found that approximately one third of them knew about amount of blood that is taken from the donor.

In contrast with our study, another study conducted by Singh et al., (2015), who found that only $5.25 \%$ of the students knew about volume of blood collected from the donor. Also, the present study result was in disagreement with Elsafi et al., (2015), who studied the awareness and practice of blood donation by college student in Dhahran, Saudi Arabia and reported that only $14.3 \%$ of them knew the correct amount per donation.

Regarding the time of blood donation, the current study showed that slightly more than two thirds of the studied student had gave correct answer about this point. This result was in agreement with Elsafi et al., (2015), who reported that slightly more than two thirds of the student knew the duration of blood donation, also these results agree with Aslami et al., (2015), who assess knowledge, attitude and practice of blood donation among student of a medical college in Kollam, Kerala .They reported about two thirds of student gave correct answer

According to the students' knowledge regarding to diseases which transmitted may be through blood donation, the current study represented that more than 
half of studied student mentioned Hepatitis C, AIDS and more than two fifths mentioned Hepatitis B. This may be because to the advertisement about Hepatitis, Aids and it's mode of transmission through mass media so they acquired more knowledge about blood donation.

The present study result were in the same line with, Safizadeh et al., (2007), who reported that more than half of their subjects mentioned AIDS and Hepatitis $\mathrm{C}$ as a blood transmitted diseases.

The present study was in disagreement with Devi et al., (2012), who carried out study to assess Knowledge, Attitude and Practice (KAP) of Blood Safety and Donation in Imphal and the found that less than one fifth of studied student mentioned Hepatitis C Virus diseases transmitted through blood, also this results disagree with Patel et al., (2015), whe studied to assess knowledge, attitude and practice of voluntary blood donation among under graduate students of medical College in India and he found that the majority of the students were aware about transmission of Hepatitis B virus but roughly $60 \%$ of them only knew the HIV transmission through the blood.

Also, the present study shows that two fifths of students gave correct answer about blood donation interval. It is may be related to blood donation Campaigns in the university. These results agreed with Singh et al., (2013), who found that about two fifths of the student were aware of interval between each donation. Also, this finding agreed with Baig et al., (2013), who carried out study in Saudi Arabia to determine the knowledge, misconceptions and motivations towards blood donation among university students and who found that two fifths of students knew appropriate interval between each time of donation

The present study results are disagreed with Thakur et al., (2015), who conducted study in India to assess knowledge and practices of blood donation among the undergraduate students of district Una, Himachal Pradesh and reported about two thirds of students gave correct answer about appropriate interval between each time of donation.

Regarding to the students' knowledge about test done before blood donation ,the present study reported that more than three quarter of studied students knew the test done before blood donation and more than half of them mentioned serology test should done before blood donation. It may explained by student knew some diseases transmitted through blood, it is important to test the blood of donor and the person to donate he to be sure that should be free from diseases The present results were in agreement with Giri \& Phalke, (2012), who found that the majority of studied student knew the test done before blood donation, in contrast with Devi et al, (2012), who reported that the majority of the student mentioned serology test for diseases

The current study showed that there was no statistical significance difference between attitude and age group, academic year or residence. These results were in the same line with Ahmed et al., (2014), who conducted study to assess knowledge, attitude and practices about blood donation among undergraduate medical students in Karachi, they reported that no statistical significance difference between attitude and age group, academic year and residence.

In addition, the present study revealed that there was a statistically significant relation between students' attitude and their sex $(\mathrm{P}=0.001)$ These results disagree with Sabu et al., (2011), who carried out a study to assess knowledge, attitude and practice on blood donation among health science students in university campus, South India. who found that no statistical significant relation between sex and their attitude on blood donation.

According to the total score of knowledge for students about blood donation, this study revealed that less than one quarter of them were poor and $12.3 \%$ of the student had good knowledge. This results disagree with Batitha \& Albashtaw, (2013), who found that most of the students had poor knowledge of the blood donation ,also disagree with Devi et al., (2012), who found that one third of the students have adequate knowledge about blood donation. It may be due to the educational program for university education doesn't contain sufficient information about the issue and the majority of students not attend any seminar about blood donation. As regards students attitude toward blood donation, the present study revealed that the vast majority of studied students had positive attitude toward blood donation while few of student had negative attitude. These results may be due to the nature of nurses work, that they aware shortage of blood in blood bank

The finding of the present study was agreed with Aslami et al., (2015), who reported that the majority of students had positive attitude toward blood donation. Also, the finding was agreed with Giri \& Phalke, (2012), who found that majority of students had positive attitude

The current study showed that there was a positive correlation between score of knowledge and attitude toward blood donation. These results were agreed with Matihas et al., (2014), who study Knowledge, Attitude and Practice of Blood Donation among adults in a rural population in Karnataka, India and found that there was a significant correlation between the knowledge scores and attitude scores 


\section{Conclusion}

Although small percent of studied students had good level of knowledge regarding blood donation, also need emphases for more information especially for technical nursing school and technical nursing institute. The vast majority of them had positive attitude .

\section{Recommendations}

The present study suggested the following recommendation

- Provide Arabic booklets for students about blood donation to increases the awareness of students regarding blood donation through pictures, poster and also mass media .

- The curriculum components of nursing students should be include the basic part about blood donation from all its aspect.

- Dissemination of a guidebook among all health and our health team regarding to donation.

- Further researcher needed about blood donation

\section{References}

1. Abd El Rhman, (2014): Knowledge and Opinionsof Assiut Unversity students toward organ donation and transplantation submitted for partial fulfillment of the requirement of the master degree in Community Health Nursing

2. Abialbon P., (2013): Health Benefits of Donating blood available athttp://www.lifehack.org/articles/lifestyle/5health-benefits-donating-blood.html

3. Ahmed Z., Zafar M., Khan A., Anjum M., \& Siddiqu M., (2014): Knowledge, Attitude and Practices about Blood Donation among undergraduate medical students in Karachi, journal infectious diseases and therapy; 2,(2):1- 4

4. Amatya M., (2013): Study on Knowledge, Attitude and Practice of BloodDonation among Students of Different Colleges of Kathmandu, Nepal, International journal of Pharmaceutical and Biological Archives,4 (3): 424-428.

5. Aslmi A., jobby A., Simon S., Nazarudden N., Raj P., Ramees M., \& Harigopal N., (2015): Assessment of knowledge ,Attitude and Practice of Blood Donation among students of a medical college in kollam, kerala, journal of evolution of medical and dental sciences; 4 (35): 6086-6095.

6. Baig M., Habib H., Haji A., Alsharief A., Noor A., \& Makki R., (2013): Knowledge, Misconceptions and Motivations towards Blood Donation, Pakistan Journal of Medical Sciences; 29(6): 1295-1299.
7. Batiha M., \& Albashtaw Y., (2013): Knowledge of Philadlphia University students regarding Blood Donation, official journal of the British Blood Transfusion Society; 23 (3):195-198.

8. Chopra D., \& Jauhari N., (2015): Knowledge ,Attitude \& Practices towards Voluntary Blood Donation among Medical Students in Barabanki. Indian Journal Community Health ;27 (3): 386390.

9. Darega B., Dida N., Tesfaye T., Lencha B., (2015): Voluntary Blood Donation Practices and Associated Factors among Regular Undergraduate University Students, Southeast Ethiopia: A Facility - Based Cross Sectional Study, Journal Blood Disorder Transfusion S5:S5-005. doi:10.4172/2155-9864.1000S5-005

10. Delaney M., (2011): Blood Center Practice and Education for blood donors with anemia ,Blood Transfusion journal ;51(5): 929-936.

11. Devi S., Laishram J., Shantibala K., \& Elangbam V., (2012): Knowledge, Attitude and Practice (KAP) of Knowledge, Attitude and Practice (KAP) of Blood Safety and Donation ,Blood Transfusion journal; 4 (2):14-20

12. Elsafi S., Al Zahrani M., \& Al Zahrani E., (2015): Awareness and Practice of Blood Donation by college students in Dhahran, Saudi Arabia, International Society of Blood Transfusion ; 10 (1): 11-17.

13. Giri P., \& Phalke D., (2012): knowledge and attitude about blood donation amongst undergraduates students of pravara institute of medical sciences demmed university of central india ,Annalks tropical medicine and public Health journal;5 (6) :569-573.

14. Kowsalya V., Vijayakumar R., Chidambaram R., Srikumar R., Reddy E., Latha S., Fathima G., \& kumar K., (2013): Study on Knowledge ,Attitude and Practice regarding Voluntary Blood Donation among medical students in puducherry India, Pakistan journal of Biological Sciences ; 16(9):439-442.

15. Majeed M., \& Lafta R., (2008): People Knowledge Regarding Blood Donation, Iraqi Journal Community Medicine; 3(4) :181-185

16. Manikandan S., Srikumar R., \& Ruvanthika P., (2013): A study on knowledge ,Attitude and Practice on Blood Donation among health professional students in Chennai ,Tamil ,south india, International Journal of Scientific and Research Publications ;3 (3) :1-4.

17. Mathias P., Murthy N., Thomas B., Anush N., Ashwini G., \& Shanbhag D., (2014): Knowledge, Attitude and Practice of Blood Donation among adults in a rural population in 
Karnataka, India, International Journal of Advanced Research ; 2 (8):430-437.

18. Mirza H., Khan F., Jabeenneem F., \& Ashra F., (2015): Blood Safety and Donation Knowledge, Attitude and Practice (KAP) among 1st Year Medical Students at , Lahore ,Transfusion Medicine Journal ; 9(3): 992-994.

19. Mortazavi Y., \& Mahmoodizadh F., (2008): study to evulation of the awareness in zanjan university about blood donation eligibility criteria, science, Journal Iran Blood Transfusion Organization ; 5(3) 195-202.

20. Olubiyi S., Babalola F., Olubiyi M., Umar N., \& Ibraheem M., (2014): Knowledge, Attitudes and Practices of blood donation among adults in Ado-Ekiti, Nigeria , Journal of Medicine and Medical Sciences ; 2 (7): 052 - 057.

21. Patel p., Patel N., Makadia K., \& Kedia G., (2015): Knowledge, Attitude and Practice of voluntary blood donation among undergraduate students of Blood Journal Medical College, Ahmedabad, International Journal of Applied Research; (9): 23-25.

22. Rehman S., Arif S., Mehdi G., Mirza S., \& Saeed N., (2012): The Evaluation of Blood Donor Deferral Causes: A Tertiary Care Centrebased Study, Journal Blood Disorders and Transfusion ; 3(5): 1-3.

23.Sabu K., Remya A., Binu V., \& Vivek R., (2011): Knowledge, Attitude and Practice on Blood Donation among Health Science in a university campus ,south India ,journal of health and allied sciences ;10(2): 1-3

24. Safizadeh H., Pourdamghan N., \& Mohamadi B., (2007): University Students Awareness and Attitude towards Blood Donation in Kerman City, Iranian journal of blood and cancer ;1(3): 107110.

25. Shenga N., Pal R., \& Sengupta S., (2008): Behavior disparities towards blood donation in Sikkim, India Asian Journal of Transfusion Science ; 2 (2): 56-60 .

26. Silva K., Barichello E., Mattia Al., \& Barbosa M., (2012): Nursing care procedures in response to adverse events to blood, Journal of Transfusion Science;23 (3) :688-695.

27. Singh S., Chandrappa M., Venkatesha M., \& Anil N., (2015): Blood donation awareness and beliefs among medical and nursing students, International Journal of Medical Science and Public Health ; 4 (10) : 1338-1342.

28. Sorensen B., Johnsen S., \& Jorgensen J., (2008): Complications related to blood donation: A population-based study ,Journal complication; 94 (2):132-1371.
29. Thakur A., Chauhan S., \& Acharya B., (2015): Knowledge and practices of blood donation among the undergraduate students of district Una, Himachal Pradesh, India, global journal of medical of and public health ; 4(6) :1-7.

30. WHO, (2012): Blood donor selection: guidelines on assessing donor suitability for blood donation available

at http://www.who.int/bloodsafety/publications/bts_ guideline donor_suitability. 